\title{
Providence and God's emergent will through prayer as it relates to determinism and healing
}

M Pretorius ${ }^{1}$

(University of Pretoria)

\section{ABSTRACT \\ Providence and God's emergent will through prayer as it relates to determinism and healing}

The paper has a twofold purpose. The first is to explore: if God has settled His plans and He will do what He is going to do, then does it matter whether one prays or not? This section will also deal with the aspect of healing and prayer, specifically from a scientific perspective. The important question is: How should one treat reports of miraculous healings, and the belief that prayer can affect healing? Secondly, if prayer has any effect on what happens, then it would seem that God's plans are not fixed in the first place, and then the idea of an open-future would seem to be valid. As a result, one could no longer see the world as a mechanistic Newtonian picture. Rather, the picture portrayed would be of a world of flexibility and openness to change. The question would then be: What is the manner and scope of divine action and wherein lies the causal joint? Regarding this, areas related to determinism will be explored as determinism states that all events in the world are the result of some previous event, or events. Bringing clarity to these questions is important, as is it has a direct bearing on how one will view miracles recorded in the Scriptures, and how far one will go in trusting God to meet one's needs through prayer.

\section{INTRODUCTION}

The first question one might ask in a debate about the providential hand of God in creation is: How should one define providence?

1 This article is based on the doctoral thesis "Understanding Reality: Exploring the Interaction between Theology and Science, with Special Reference to a Theistic Presupposition to Certain Worldviews”. The thesis, with Prof Johan Buitendag as supervisor, was accepted and successfully defended in June 2007 in the Department of Dogmatics and Christian Ethics, Faculty of Theology, University of Pretoria. 
Polkinghorne (1998:84-85) refers to providence as Divine action in the world. From a theological and scientific view, he sees providence divided into three levels.

General providence. This is the divine sustaining of the order of the world, in which one understands the laws of nature as expressions of God's faithfulness. The deist, as much as the theist, will accept this idea.

Special providence. This view concerns itself with particular Divine actions within cosmic history. One understands it as taking place within the grain of physical process, thus not immediately distinguishable from other happenings. God may act through famine or through times of plenty, and this may be recognisable by faith, but it will not be demonstrable to the sceptic.

Miracle. The concern here is with radically unnatural events, such as turning water into wine or restoring the dead to life. If such things happen, their very nature suggests that they are the effects of Divine action of an unusual kind.

For Polkinghorne, these categories are not entirely sharply defined. There are some events, such as those that might be interpretable as highly significant coincidences, which might seem to fall into a grey borderline area. Nevertheless, the classification provides a useful taxonomy for thinking about possible Divine acts.

As a result, in recent writings about science and theology there has been much discussion of God's action in the world. The following paper is presented to survey some of the suggestions put forward. But, before one ventures any further, a problem that has concerned thoughtful Christians when considering the nature of providence, is the role of prayer, and how it links to miraculous events; specifically the healing of one's body. Every committed Christian wants to believe that prayer makes a difference. What is the point in praying, according to Ware (2000:164), if prayer itself turns out to be superfluous and ineffectual?

One should note from the start of this discussion, that these questions are simply one particular form of the larger issue of the relationship between human effort and Divine providence. Barth (1958:148) defines Divine providence in terms of the sovereignty of God when he states that: 
God "rules unconditionally and irresistibly in all affairs... Nature is God's 'servant', the instrument of His purposes... God controls, orders, and decides, for nothing can be done except the will of God... God foreknows and predetermines and foreordains".

Although this statement might be biblically true, it does appear from Scripture that God often works in a sort of partnership with humans. As a result, it seems as if God does not act if humans do not play their part. Therefore, when Jesus ministered in His hometown of Nazareth, He did not perform any major miracles; all He did was heal a few sick people. Scripture states that Jesus, "was amazed at their lack of faith" (Mk 6:6) suggesting that the people of Nazareth simply did not bring their needy ones to Him for healing. Often the act of faith was necessary for God to act, but it seems that this was lacking in Nazareth.

When it comes to prayer and Divine providence, Thiessen (1979:129) states that some hold that prayer can have no real effect on God, since He has already decreed just what He will do in every instance; he does argue that this is an extreme position. One must not ignore James 4:2, "You do not have because you do not ask". God does some things only in answer to prayer; He does other things without anyone's praying; and He does some things contrary to the prayers made. In His omniscience He has taken all these things into account, and in His providence He sovereignly works them out in accordance with His own purpose and plan. Thiessen (1979:129) further argues:

If we do not pray for the things that we might get by prayer, we do not get them. If He wants some things done for which no one prays, He will do them without anyone's praying. If we pray for things contrary to His will, He refuses to grant them. Thus, there is a perfect harmony between His purpose and providence, and man's freedom.

In this regard, an area one would need to consider is the contentious issue about the belief that God heals when one prays.

\section{PROVIDENCE IN PRAYER AND HEALING}

The twentieth and early twenty-first century has seen a remarkable growth in interest in the subject of spiritual healing of the body. This 
has come in three related but distinct stages of movements according to Erickson (2001:852-853). First is the Pentecostal movement, which arose and grew in the United States in the early part of the twentieth-century. This stage stressed the return of certain of the more spectacular gifts of the Holy Spirit. Then, about the middle of the century, the Neo-Pentecostal or Charismatic movement began; it had many of the same emphases. In the 1980s and onwards the "Third Wave" arose. These movements put greater stress on miracles of spiritual healing than does Christianity in general. Often they make no real attempt to give a theological explanation or basis for these healings. But when one raises the question, the answer often given is that healing, no less than forgiveness of sins and salvation, is found within the atonement. Christ died to carry away not only sin, but sickness as well. Among the major supporters of this view was A B Simpson, founder of what today is known as the Christian and Missionary Alliance.

One of the striking features of the view that Christ's death brings healing for the body, according to Simpson (1880:30-31), is the idea that the presence of illness in the world is a result of the fall. When sin entered the human race, a curse (actually a series of curses) was pronounced on humanity; diseases were part of that curse. According to Simpson and others, since illness is a result of the fall, not simply of the natural constitution of things, one cannot combat it solely by natural means. Being of spiritual origin, one must combat it in the same way one combats the rest of the effects of the fall: by spiritual means, and specifically by Christ's work of atonement. Intended to counter the effects of the fall, His death covers not only guilt for sin but sickness as well. Healing of the body is, therefore part of a Christian's great redemption right.

Unfortunately, this is in stark contrast to various researches undertaken over many decades to study the area of healing; specifically when it comes to prayer for healing. The following is a breakdown of these findings.

\section{HISTORICAL ASPECTS OF PRAYER AND MEDICINE}

In various interviews and surveys undertaken over several decades by prominent scientists and medical doctors (Meyers and Benson 1992; Angel 1985; Kleinman et al 1978; and Engel 1977), it was found that most people believe that not only does the mind affect the body (a view with which most scientists would agree), but there are 
also supernatural forces that have an intense affect on one's physical and emotional well-being (a view with which most scientists would disagree). From a scientific perspective, the important question is: How should one treat reports of miraculous healings, and the belief that prayer can effect healing? Is there a special connection between belief in the supernatural and physical well-being? With the accelerating technical advances of Western medicine, there are increasing patient complaints against the medical community for their exclusionary focus on the biomedical model of disease. According to these surveys, it would seem that many patients, particularly if their disease is severe, want metaphysical as well as medical interventions, that is, they want a direct link from their medical care to God.

In later studies, and in response to these findings, McCullough (1995:15-29) in a review of the prayer literature, considered the following four areas of prayer research.

- Prayer and subjective well-being;

- Prayer as a form of coping;

- Prayer and psychiatric symptoms;

- Intercessory prayer.

He reported that both the frequency of prayer and the presence of mystical and religious experience during prayer were predictive of subjective well-being on many indexes. It was, however, stated that several confounds in the studies reviewed, rendered the data interpretation problematic. Variables such as religious commitment and socio-demographics were not controlled. As a result, if one prays often but has little commitment to religious belief one may predict that the positive effects on subjective well-being might diminish.

McCullough further noted that the use of prayer is more often for symptoms treated with medication, and discussed with a doctor, than those that have not. One obvious problem found is that prayer as an effective coping response is confounded with medical treatment. Thus, as one experiences the effect of the medical treatment, there might be a tendency to credit change to prayer.

One might ask: What about intercessory prayer (IP), or the act of praying for another? Sir Francis Galton (1872:125-135) was the first to apply statistical analysis in trying to determine the effects of 
IP. While his data collection method was flawed, he inferred that IP was not a significant predictor of life span or social class. Since Galton's study in 1872, there have been six empirically based studies looking into the effect of intercessory prayer. These studies, undertaken by Collipp (1969:201-204), Elkins et al (1979:81-87), Joyce and Weldon (1965:367-377), O'Laoire (1997:38-53), Wirth and Barret (1994:61-67) centred mainly around the effect of prayer on various medical conditions of adults and children. The results recorded, found no statistically significant effect of intercessory prayer for these patients. Green (1993:2752), however, did find positive expectancy (the belief in the effectiveness of prayer) in relation to IP to have a significant effect on patient anxiety levels. Thus, for those patients who had a high expectancy for the effectiveness of prayer to reduce anxiety, anxiety was reduced. But these studies do not validate or deny the effect of prayer. The question therefore remains unanswered: Does prayer work?

\section{PSYCHOLOGY AND PRAYER}

The question one might now ask is: Should medical doctors or psychologists advise their patients to pray? According to Sloan et al (1999:664-667), "it is premature to promote faith and religion as adjunctive medical treatments”. According to them, so far, the existing research on the effect of prayer is so flawed in terms of controlling for viable alternative theories and the likelihood of errors, that belief in prayer for physical and emotional well-being is simply unwarranted. However, the empirical evidence strongly suggests that expectancies for desired outcomes, social connectedness, and deep religious positive expectancies may be effective buffers for the stressors associated with various medical conditions. As such, any intervention that improves patient wellbeing is valuable. One could also ask: What is the role of psychology in understanding the effectiveness of prayer in one's life?

The study of prayer in the early history of modern psychology was, without doubt, a thriving concern (see Pratt 1908; Strong 1909). In the years that followed, however, the study of prayer dropped dramatically, following the general trend of declining interest in the relation between psychology and religious beliefs (see Spilka and McIntosh 1999). However, during the last several years, researchers have revisited the topic of prayer (see Hood et al 1993; Ladd and Spilka 2002; Laird et al. 2001; Poloma and Gallup 1991). Consequently, Ladd and Spilka (2002) proposed an explicit 
theoretical basis for understanding prayer as a means of forming cognitive connections. One should note that none of these proposals was based on the premise that one was dealing with a personal God when praying. As a result, one might then ask: What has this to do with providence?

The reason why the author has brought this into the discussion is to show that many pray without really believing that anything will happen, except within them. And, of course, the person praying has the comfort of knowing that they have someone they can talk to, whether the wanted outcome of the prayer manifests itself or not (this is explored further on). Thus, according to the research conducted by Ladd and Spilka (2002:234), prayer contains inward, outward, and upward dimensions as postulated by the research conducted by Foster (1992). The theory behind this is that inward prayers emphasize self-examination. Outward prayers focus on strengthening human - to - human connections. Upward prayers centre on the human-Divine relationship.

Besides the directionality of prayer put forth, Ladd and Spilka (2002) also reported three second-order factors, referred to as higher orders that appear to represent the intentionality of prayer.

- Higher order factor one, consists of content stressing intercession.

> Outward: Prayer on behalf of someone's difficulties.

Outward: Prayer to share another's pain.

Inward: Prayer to evaluate one's spiritual status.

In broad terms, it seemingly represents a way of connecting which highlights the internal conditions of others as well as oneself. Engaging in intercessory prayer compels recognition of another's inner struggle, even as examination prayer evaluates one's own private situation. Perhaps even more intense is the prayer of suffering or the willingness to enter someone else's pain to provide comfort.

- The second higher order factor encompasses prayers of rest.

Upward: Searching for stillness, sacrament.

Upward: Encountering tradition, and tears.

Inward: Experiencing personal turmoil. 
Here, connections with the Divine appear to provide both peace and pain. These mixed experiences of spiritual pleasure and pain are not uncommon (cf. Weil 1951).

- The third higher order factor is marked by:

Outward: Assertiveness and petitionary prayer.

Outward: Material request approaches to praying.

No inward experience is recorded here.

This factor shows connections based on a bold use of prayer. Instead of abandoning one's needs, this type of prayer puts those needs at its centre. The research conducted did not refer to any empirical data stating whether any of the needs prayed for were received.

Doubtless, what these researchers have uncovered and systemised is correct, and does throw more light on the subject of prayer. The problem is that it fails to answer the question of God's involvement in one's prayers, other than at a superficial level. The comfort of knowing that from an inward, outward and upward belief, prayer does, to a degree accomplish something; is not enough in the author's view.

It is unfortunate that many of the studies undertaken around prayer and healing were based on empirical data, inclining to ignore the omnipotence and omni-benevolence of God. It was also not pointed out whether or not any of the subjects interviewed, or the scientists conducting the experiments, had a believing trusting faith in God, even though they did pray. So far, the author of this paper has not found any major research undertaken by evangelicals to counter-claim these scientific findings. It is also unfortunate that many scholars, even those in the theological disciplines, are sceptical, when it comes to anything related to healing or any miraculous events. Bultmann (1958:16), for example, asserted that miracles were "myths". He wrote, "Modern men take it for granted that the course of nature and history...is nowhere interrupted by the intervention of supernatural powers”.

The question remains as to why the Bible would instruct Christians to pray in all circumstances, if God were not going to answer any of their prayers, specifically prayers for healing. Although it was suggested that the research data presented was flawed, and that much research is still needed, one might well ask the question: Is that a good enough answer when reading the 
negative statements made within these studies about the relationship between God, prayer and healing?

In all fairness, one must say that science deals with facts. Facts, according to Barton (1999:17), are the instruments that the natural scientist uses to build a coherent framework for understanding the world. The problem is that as this framework has developed, it has conflicted with religion and will continue to be in conflict with religion in future studies that it undertakes, until common ground is reached between the two disciplines. The reason being, as science is exposed to new data it is subject to change, and is therefore continuously evolving. One could say that there are no absolutes at this point in the scientific world, especially in its understanding of prayer. None of the scientists quoted can claim that his or her observations have earned the status of ultimate truth. In this vein, the following letter sums up what the general consensus is, on the limits of science.

In a letter written to the scientific magazine Nature, Donald MacKay (1997:502) from the Department of Communications and Neuroscience, at University of Keele in the United Kingdom wrote;

In scientific laws we describe, as best we can, the pattern of precedent we observe in the sequence of natural events. While our laws do not prescribe what must happen, they do prescribe what we ought to expect on the basis of precedent. If by a "miracle" we mean an unprecedented event...then science says that miracles ought not to be expected on the basis of precedent. What science does not (and cannot) say...is that the unprecedented does not (or cannot) occur...We cannot dogmatically exclude the ever present possibility that the truth about our world is stranger than we have imagined.

Although, as previously suggested, doubtless, science has achieved enormous success as ways of knowing the structures and processes of the material world, physical science, it appears that it leaves no place for Divine action. One should also declare that it is a human moral trait to seek explanations. Regardless of whether this is in science, or any other discipline, each could claim that he or she is doing research simply for the very sake of understanding how nature works. This is irrespective of whether it is in religion or any other 
field that deals with unexplainable events, for example, the discipline of quantum physics.

Natural science needs to understand that, if breakthroughs are to be achieved in the dialogue between science and religion, scientific methods - as advanced as they are - hold no intrinsic guarantee that it could lead to ultimate truth. This is specifically so when it comes to unexpected happenings, that is, when one prays and things happen.

Regarding this, Bloesch (1978:58) writes:

Evangelical prayer is based on the view that a sovereign God can and does make Himself dependent on the requests of His children. He chooses to realise His purposes in the world in collaboration with His people. To be sure, God knows our needs before we ask, but He desires that we discuss them with Him so that He might work with us as His covenant partners toward their solution. There is, of course, a time to submit as well as a time to strive and wrestle with God in prayer, but this should come always at the end of prayer and never at the beginning. Moreover, our submission is not a passive resignation to fate but a relinquishing of our desires and requests into the hands of a living God to answer as $\mathrm{He}$ wills.

A question that would now seem to surface is: How does God influence humanity regarding prayer and His answering of it, and how does this in turn affect surrounding reality to bring about Gods Divine will?

\section{DETERMINISM}

According to Barrett (2004:142), Divine action is a long-standing topic of debate. If the world is no longer construed in terms of the mechanistic Newtonian picture but rather as a world of flexibility and openness to change, what is the manner and scope of Divine action and wherein lies the causal joint? It is fairly obvious from the empirical data thus far presented, that the causal joint to bring about change is not found in prayer. Thus, how or where does God actually act? Furthermore, has God in eternity past determined the course of all future events - this will thus make prayer even more irrelevant unless another reason can be found for prayer. Doubtless, 
Determinism and Divine Causality have far-reaching implications concerning prayer and hence require a more than superficial investigation. Therefore, the first area one would need to consider is the act of determinism.

One area of contemporary discourse in science that relates to the issue of human freedom is the notion of genetic determinism. Here, the concept of determinism is linked directly to the genes in the DNA of a person. Because one already knows that aberrations in certain genes can lead to various forms of physical and mental disease in humans, one can say with some certainty that people are physically determined by their genes. But genetic determinists want to extend this further, by claiming that even one's behaviour is determined by one's genes. In this line of thinking, humans are but victims of their genetic makeup, and any effort to change their moral nature or behavioural patterns would be futile.

Thus determinism states that all events in the world are the result of some previous event, or events. Accordingly, all of reality is already in a sense predetermined or pre-existent, therefore nothing new can materialise. Thus the obvious question: Why pray?

To begin, this closed deterministic view sees all events in the world simply as effects of other prior effects - a sort of Supervenience or Emergence taken place - and has particular implications for morality, science, and religion. Ultimately, if determinism is correct, then all events in the future are as unalterable as are all events in the past. Consequently, human freedom is simply an illusion and the need of prayer irrelevant in changing surrounding reality, as its course of action - in a sense - has already been determined. The question then is: How does this affect or impact on humanity's ability to make free choices and plot their own future, specifically when praying for change, either inwardly or outwardly?

Regarding determinism, Murphy (1995) has proposed that God determines all quantum indeterminacies. However, God does arrange that law-like regularities usually result, in order to make stable structures and scientific investigation possible. Thus, God ensures that human actions have dependable outcomes, so that moral choices are possible. As such, orderly relationships do not constrain God, since He includes them in His purposes. Murphy holds that in human life God acts both at the quantum and at higher levels of 
mental activity, but does it in such a way that it does not violate human freedom.

Mindful of this, an alternative would be to say that while most quantum events occur by chance, God “influences" certain quantum events without violating the statistical laws of quantum physics (see Russell 1998). However, a possible objection to this model is that it assumes bottom-up causality within nature once God's action has occurred. This, in turn, seemingly concedes to the reductionism's claim that the behaviour of all entities is determined by their smallest parts - cells (or lowest levels). The action would be bottom-up even if one assumed that God directed His intents to the larger wholes (or higher levels) affected by these quantum events. However, most scholars in this field also allow for God's action at higher levels, which then results in a top-down influence on lower levels, as well as quantum effects from the bottom-up (see Gregersen 2000:155157; Clayton 1997:252-257).

In line with this, Peacocke (1993:215) says that without argument, God exerts a-top-down causality on the world. It must be stressed that Peacocke is influenced by the panentheistic view, and is very much in favour of an open-theistic view of the future. In his view, God's action is a boundary condition or constraint on relationships at lower levels that does not violate lower-level laws. Generally, boundary conditions may be introduced not just at the spatial or temporal boundaries of a system, but also internally through any additional specification allowed by lower-level laws. In human beings, God could influence the highest evolutionary level that of mental activity - thereby changing the neural networks and neurons in the brain.

Peacocke maintains that Divine action is effected in humans down the hierarchy of natural levels; hence one has at least some understanding of the relationships between adjacent levels. Thus Peacocke suggests that God communicates His purposes through the pattern of events in the world. Consequently, one can then look on evolutionary history as acts of an agent who expresses purposes, but does not follow an exact predetermined plan - open theism. Moreover, he says, God influences one's memories, images, and ideas, just as one's thoughts influence the activity of neurons. Furthermore, Peacocke states that Christ was a powerfully Godinformed person who was a uniquely effective vehicle for God's self-expression, so that in Christ, God's purposes are more clearly 
revealed than in nature or elsewhere in history. In the author's view Peacocke's ideas seem to lean towards process theology or as stated, the openness view of God, which, to a certain extent, relies on chance as the determiner of all future events. The reason being, God, in the openness view, relies on humanity making decisions, through free-choices, that will hopefully line up with His determined plan. . Regarding this type of freedom, Barbour (2000:127) states "We cannot choose the cards we have been dealt, but we can to some extent choose what we do with them”.

As such, ideas of top-down causation are called forth by both Peacocke (1993:157-16) and Polkinghorne (1998:60; 1996:31-32), but in different ways. As mentioned, Peacocke speaks of the relationship between Creator and creation in panentheistic terms, placing great emphasis on the immanence of God, who is all the time creating in and through the processes of the world. According to him, these processors are, in themselves, God's action and thus constrained to be what they are in all their subtlety and fecundity by virtue of the way God interacts with the world-as-a-whole. Knowing the interconnectedness of the world to the finest detail, one thus envisages God as being able to interact with the world, "at a Supervenient level of totality" - Holistically - thereby bringing about particular events and patterns of events, that is, His predetermined plan. Such interaction amounts to the input of information, which by nature forms patterns, the energy content of which can be vanishingly small, so that there is no breach in the causal network of natural law. Indeed, it is a form of top-down causation that Peacocke prefers to call whole-part influence. As such, it meets his concern always to interpret the world's happenings as naturalistically as possible, seeing this as a crucial task of theology in the scientific age.

In the view of Barbour (2000:111),

The idea of top-down causality has also been extended by theologians who suggest that God acts as a top-down cause from a higher level without violating the laws describing events at lower levels. God would be the ultimate boundary condition, setting the constraints within which events in the world occur.

Consequently, Polkinghorne also speaks of top-down causality through providing similarly energy-less active information, although 
he suggests a more direct input into the world's processes - the chaos concept. With the chaos concepts of butterfly effect and strange attractor in mind, it is conceivable that pattern-forming information can lead a system from one arrangement to another. Meaning, since any trajectory from one point within its strange attractor to another does not involve any change of total energy thus, Polkinghorne suggests, the Divine will could be exerted within any macroscopic part of the world's structure. Besides, he also believes that there is a greater dynamical openness for Divine agency via chaotic systems than simply through holistic operation on the world-as-a-whole. As such, when challenged, macroscopic physical systems - even in their chaotic mode - follow deterministic equations and therefore cannot be expected to offer any room for manoeuvre. Accordingly, Polkinghorne (1998:36) states that the equations can be understood as estimations to true physical reality, applicable in only those rare and specific situations, in which a system can be treated as totally isolated from its environment.

According to Barrett (2004:146), the idea of Divine providential action through the hidden, introduced active information that is consonant with that of a gracious Creator, a Creator who allows the creation to be itself and to have room to develop. This development takes place through the exercise of human free will and the pathways of free process, via divinely installed guiding principles of chance and necessity - Is this perhaps again a subtle form of open theism? In Christian theology it is the Creator-Spirit, who is thus creatively at work throughout space-time. This Spirit of Life, referred to by Taylor (1972:27-28) as the Go-Between God,

is ever at work in nature, in history and in human living, and wherever there is a flagging or corruption or selfdestruction in God's handiwork, he is present to renew and energize and create again.... If we think of a Creator at all, we are to find Him always on the inside of creation. And if God is really on the inside, we must find Him in the process, not in the gaps. We know now that there are no gaps... If the hand of God is to be recognised in His continuous creation, it must be found not in isolated intrusions, not in any gaps, but in the very process itself.

At this point, one could explore what some call Metaphysical Determinism (see Rychlak 1981; 1988 and Viney \& King 1998) 


\section{METAPHYSICAL DETERMINISM}

In this view, all events in the universe including organismic behaviour are necessary outcome of antecedent conditions. Nothing but the behaviour that did occur could have occurred, given the antecedent causal circumstance.

As such Nevin (1991) and Baum (1994) have made statements that appear to be compatible with metaphysical determinism. For example, Nevin (1991:36) makes clear: "According to the most central tenets of our creed, all behaviour is determined by genetics and environmental processes". Similarly, Baum's (1994:11-14) remarks on determinism are easily interpreted as metaphysical in nature. He considers determinism to be "the notion that behaviour is determined solely by heredity and ones environment”.

One could look at this from another perspective. In the view of Byl (2003:106), although God is the primary cause of everything according to Col 1:16-17 and Heb 1:3, He usually works through secondary causes. In sustaining the universe from one moment to the next, God generally does so by the properties He has assigned to humans. Thus God usually permits humans to act according to their natures. In particular, He normally allows humans to do what they want, making their own decisions. Yet these human choices cannot be put into actions without God's concurrence or cooperation. God could, in a sense, place laws of determinacy into cells at the quantum level. From this a determined emergence could occur throughout the different levels till it reaches the mental states (see Murphy 1996:23). From this mental state, ideas could emerge - one could call them God ideas (see Barbour 2000:170). It is at this level that one could either determine or reject, by an act of free-will, to go forward with the emerging ideas to bring about changes in the natural realm of reality. For Murphy (1996:25), this is where topdown action occurs; when human volition is involved. Consequently, this brings about the necessary causal changes with the capacity to influence that which sustains its very existence - the natural realm. One then has the combination of upward determinism and downward causation. This then brings about human experience which then changes and adjusts human nature as God would have. One could in a sense say that prayer is the causal joint to start the process of bringing about His will on this earth as the person praying, to a large degree, is rendering their will to a higher power. Thus every normal natural event has two causes; a primary Divine cause and a 
secondary, natural cause. At this point, one could actually say that miracles occur in those extraordinary cases (Divine healing for example) when God withholds His concurrence and substitutes some other effect.

But despite all said, the question of whether God answers specific prayer remains unanswered, and, one can then only hypothesise as to how God works at the quantum level, or for that matter at any level He chooses. But, in saying this, could it perhaps be that prayer does not concern God as a means of fulfilling His will on this earth, as He has already predetermined His will through bottom-up and top-down emergent properties?

Consequently, one could consider an alternative view expressed by some scholars when dealing with the issue of prayer. Some maintain that the idea of prayer is more to do with soliloquy, reflection on life and inner change, rather than to change the mind of God.

\section{IS PRAYER ONLY A MEANS OF INWARD CHANGE?}

Moltmann (1996:247-249), who breaks with monotheism and embraces a Hegelian form of panentheism (see Heiler 1958), contends that one can no longer pray to God but only in God, that is, in the spirit of God. Accordingly then, one reinterprets prayer rather as soliloquy, reflection on life or meditation on the ground of being. Some theologians (see Tillich 1957 and Schleiermacher 1963) believed that prayer should only take the form of gratitude, resignation, or meditation, rather than a petition to alter the ways of God. In other circles, prayer is interpreted and understood as a consciousness-raising experience which brings one into tune with the infinite. This is very much in line with the findings undertaken by Green (1993:2752) and Sloan et al (1999:664-667) who stated that for those patients, who had a high expectancy for the effectiveness of prayer to reduce anxiety, anxiety levels were indeed reduced and might also have been effective buffers for the stressors associated with various medical conditions.

What these researchers, in the author's view, fail to recognise is that prayer is an essential element in the totality of Christian living, especially regarding intercessory prayer. Paul, writing to Timothy states the following in I Timothy 2:1-2, "I urge that supplication, prayers, intercession, and thanksgiving be made for all men, for kings and all who are in high positions”. While no sharp 
distinction can be drawn between "supplications" and "intercessions", petitionary prayers are offered on behalf of others. But this does not, unfortunately, answer the question: Does God heal at one's request, or at the request of others, as in intercessory prayers offered on behalf of others?

Packer (1997:29) clearly and rightly addresses this contentious area of God's providence and healing in the following way:

Petitions for healing or anything else, are not magic spells, nor do they have the effect by putting God under pressure and twisting His arm...Non Christian prayers for healing may surprise us by leading to healing; Christian prayers for healing may surprise us by not being answered that way. There are always surprises with God. But with God's children 'Ask and you will receive' is always true, and what they receive when they ask is always God's best for them long-term, even when it is a short-term disappointment. Some things are certain, and that is one of them.

Furthermore, one could also say that as one submits to God, so the ideas and desires about what to pray, subtly come on a person's thoughts through emergent properties determined by God at the quantum cell level, or gene level. Thus, when one prays those ideas and thoughts that emerge, one is, in a sense, praying God's determined will on the earth, and as a result, things begin to change in the physical which then, as discussed, impacts on human experience and then changes and adjusts human nature as God would have.

In this way, both the determinist and the libertarians concerns regarding God's Divine acts and humanity's free-will are addressed. Although much research is still required in this most intriguing area, one thing is clear. God will bring about His will on the earth, regardless of whether humanity works with Him or not.

\section{SUMMARY AND CONCLUSIONS}

In conclusion, one might again ask the question: Does God answer prayer, and how is it accomplished? Furthermore, what is a miracle, whether that is around healing or any other suspension or alteration of natural laws, to a scientist and to a theologian? 
Firstly, the author began by looking at what providence consists of and how scholars view providence. The conclusion was that one could interpret providence in several ways, depending on what conclusion one hopes to reach.

The question of prayer and its relationship to providence were explored, to see how they link up, and whether God's plans are fixed and unchangeable. The determination is that God is able to work His plans within nature without violating human freedom through bottom-up and top-down causality. Although areas of emergence and supervenience were used to make a case for Divine causality, it was nevertheless stated that this is only a hypothesis and further research is no doubt still needed in this intriguing area.

It was also presented that one could envisage God, who, knowing the interconnectedness of the world to the finest detail, is able to interact with the world "at a Supervenient level of totality" Holistically - thereby bringing about particular events and patterns of events, that is, His predetermined plan

It was also presented that for some, prayer is not a means that God uses to accomplish His plans, rather, prayer is more to change the person praying then to change Gods mind. Regarding this, it was put forth that what these researchers, in the authors view, fail to recognise is that prayer is an essential element in the totality of Christian living, especially regarding intercessory prayer. Paul writing to Timothy states the following in 1 Timothy 2:1-2: "I urge that supplication, prayers, intercession, and thanksgiving be made for all men, for kings and all who are in high positions". Thus prayer is not simple a method God uses to change people, but also a method God uses to change circumstances to bring about His will in the earth. One could in a sense say that prayer is the causal joint to start the process of bringing about His will on this earth as the person praying, to large degree, renders their will to a higher power which brings about the changes asked for. This in turn brings about the necessary changes both inwardly and outwardly.

Regarding miraculous events, some might simply see them as illusions - events that are really fabrications, coincidences, or the results of some mysterious power of the mind or an unknown law of nature and not of any Divine activity. In other words, there are no miracles; theologically speaking, there are only unusual events. This, of course, is a hypothesis that remains to be proven. But if part of the 
cause of a miraculous event is Divine providence, then, to a scientist, a miracle, whether that be a supernatural causal event, or a healing taking place within a person, will appear simply as an inexplicable event - a mystery that seemingly goes beyond what one can explain by natural cause.

If, on the other hand, one suggests Divine providence, miracles should then be of interest to all those who are trying to understand how God acts in the world. To the believer then, the providence of God is not an abstract conception. It is the believer's conviction that he or she is in the hands of a wise and powerful God, who will accomplish His purposes in the world, whether or not the prayer for healing or any other need is answered or not.

\section{Consulted literature}

Angel, M 1985. Disease as a Reflection of the Psyche. New England Journal of Medicine 312, 1570-1572.

Barbour, I G 2000. When Science meets Religion. London: Society for Promoting Christian Knowledge.

Barrett, P 2004. Science and Theology since Copernicus. London: T\&T Clark International.

Barth, K 1958. Church Dogmatics Vol III/4. Edinburgh: T\&T Clark.

Barton, A 1999. Questions of Science: Exploring the Interaction between Science and Faith. Eastborne: Kingsway Publications.

Baum, W M 1994. Understanding Behaviourism: Science, Behaviour, and Culture New York: Harper Collins.

Bloesch, D G 1978. Essentials of Evangelical Theology Volume Two: Life Ministry and Hope. San Francisco: Harper Collins.

Bultmann, R 1958. Jesus Christ and Mythology. New York: Charles Scribner's Sons.

Byl J 2003. Indeterminacy, Divine Action and Human Freedom. Science \& Christian Belief 15(2), 101-116.

Clayton, P 1997. God and Contemporary Science. Grand Rapids: Eerdmans

Collipp, P J 1969. The Efficacy of Prayer: A Triple Blind Study. Medical Times 97(5), 201-204.

Elkins, D K Anchor, N \& Sandler, H M 1979. Relaxation Training and Prayer Behaviour as Tension Reduction Techniques. Behavioral Engineering 5(3), 81-87.

Engel, G 1977. The Need for a New Medical Model: A Challenge for Biomedicine. Science, 196, 129-135.

Erickson, M 2001. Christian Theology. Michigan: Baker Books. 
Foster, R 1992. Prayer. Finding the Heart's True Home. New York: Harper Collins.

Galton, F 1872. Statistical Inquiries into the Efficacy of Prayer. Fortnightly Review 12, 125-135.

Green, W M 1993. The Therapeutic Effects of Distant Intercessory Prayer and Patients' Entranced Positive Expectations on Recovery Rates and Anxiety Levels of Hospitalized Neurosurgical Pituitary Patients: A Double Blind Study Dissertation. Abstracts International 54 (5-B), 2752.

Gregersen, N H 2000. God's Public Traffic: Holist verses Physicalist Supervenience in: Gregersen, N H Drees, W B and Görman, U (eds). The Human Person in Science and Theology. Grand Rapids Michigan: Eerdmans.

Heiler, F 1958. Prayer: History and Psychology, edited and translated by McComb, S. New York: Oxford University.

Hood, et al 1993. November. Religiosity, Prayer, and their Relationship to Mystical Experience. Paper presented at the annual meeting of the Religious Research Association. Raleigh, NC.

Joyce, C R B \& Weldon, R M C 1965. The Objective Efficacy of Prayer A Double-Blind Clinical Trial. Journal of Chronic Diseases 18, 367-377.

Kleinman, A Eisenberg, L \& Good, B 1978. Culture, Illness, and Care: Clinical Lessons from Anthropologic and Cross-cultural Research. Annals of Internal Medicine, 88, 251-258.

Ladd, K L \& Spilka, B 2002. Inward, Outward, Upward: Cognitive aspects of Prayer. Journal for the Scientific Study of Religion 41(3), 475-84.

Laird, S P Snyder, C R Rapoff, M A \& Green S 2001. Measuring Private Prayer: The Development and Validation of the Multidimensional Prayer Inventory. Paper presented at the meeting of the American Psychological Association, San Francisco, CA.

MacKay, D 1997. Letter to the Editor. Nature 311, 502.

McCullough, M E 1995. Prayer and Health: Conceptual Issues, Research Review, and Research Agenda. Journal of Psychology and Theology 23(1), 15-29.

Meyers, S S \& Benson, H 1992 Psychological Factors in Healing: A New Perspective on an Old Debate. Behavioral Medicine 18, 5-11.

Moltmann, J 1996. The Coming of God. Minneapolis: Fortress Press.

Murphy, N 1995. Divine Action in the Natural Order: Buridan's Ass and Schrödinger's Cat. In Chaos and Complexity: Scientific Perspectives on Divine Action, ed. Robert John Russell, Nancy Murphy, and Arthur R Peacocke 325-57. Vatican City State: Vatican Observatory, and Berkeley: Center for Theology and Natural Sciences.

Murphy, N \& Ellis F R 1996. On the Moral Nature of the Universe: Theology, Cosmology and Ethics. Minneapolis: Fortress Press. 
Nevin, J A 1991. Beyond Pride and Humility. The Behaviour Analyst 14, 35-36.

O' Laoire, S 1997. An Experimental Study of the Effects of Distant Intercessory Prayer on Self-Esteem, Anxiety, and Depression. Alternative Therapies 3(6), 38-53.

Packer, J I 1997. When Prayer doesn’t Work. Christianity Today 416 Jan.

Peacocke, A 1993. Theology for a Scientific Age. London: SCM.

Polkinghorne, J 1998. Science and Theology. Minnesota: Fortress Press

Poloma, M M \& Gallup, G H (Jr) 1991. Varieties of Prayer: A Survey Report. Philadelphia PA: Trinity Press.

Pratt, J B 1908. Psychology of Religious Belief. New York: Macmillan.

Russell, R J 1998. Special Providence and Genetic Mutation: A New Defense of Theistic Evolution. In Evolutionary and Molecular Biology, ed. Robert John Russell, William Stoeger and Francisco Ayala, 191-223. Vatican City: Vatican Observatory Publications, and Berkeley: Center for Theology and the Natural Sciences.

Rychlak, J F 1981. Personality and Psychotherapy: A Theory Construction Approach. Boston: Houghton Mifflin.

Schleiermacher, F 1963. The Christian Faith, vol 2, Mackintosh H R and Stewart, J S (eds). New York: Harper Torch Books.

Simpson, A B 1880. The Gospel of Healing. New York Christian Alliance

Sloan, R. Bagiella, E \& Powell, T 1999. The Lancet, 353, 664-667.

Spilka, B \& McIntosh, D N 1999. Bridging Religion and Psychology: The Hall-James Generation as Transition from the "Old" to the "New" Psychology, in: Rector L J and Santaniello, W (eds.), Psychological Perspectives and the Religious Quest: Essays in Honour of Orlo Strunk, 740. New York: University Press of America.

Strong, A L 1909. The Psychology of Prayer. Chicago: University of Chicago Press.

Taylor, J V 1972, The Go-Between God. London: SCM Press.

Thiessen, H C 1979. Lectures in Systematic Theology Grand Rapids Michigan: Eerdmans.

Tillich, P 1957. Systematic Theology. Vol 2. Chicago: University of Chicago.

Tupper, F E 1985. The Providence of God in Christological Perspective. Review and Expositor 82(4) ATLA Religion Database.

Viney, D W \& King, D B 1998. A History of Psychology: Ideas and Context $\left(2^{\text {nd }}\right.$ ed) Boston: Allyn \& Bacon.

Ware, A B 2000. God's lesser Glory: The Diminished God of Open Theism. Wheaton Illinois: Crossway Books.

Weil, S 1951. Waiting for God. New York: Putnam. 
Williams, J R 1996. Renewal Theology; Three Volumes in One. Grand Rapids Michigan: Zondervan.

Wirth, D P \& Barrett,M J 1994. Complementary Healing Therapies. International Journal of Psychosomatics 41(1-4), 61-67. 